\title{
Potensi Pemanfaatan Nipah (Nypa Fruticans) sebagai Pangan Fungsional Dan
}

\section{Farmasetika}

\section{Potential Utilization of Nipah (Nypa Fruticans) as Functional Food And Pharmaceutical}

\author{
Ikhsanul Khairi*1, Samsul Bahri ${ }^{2}$, Nabila Ukhty ${ }^{3}$, Anhar Rozi ${ }^{4}$, Muhammad Arif Nasution ${ }^{5}$ \\ 1,3,4 Jurusan Perikanan, Fakultas Perikanan dan Ilmu Kelautan, Universitas Teuku Umar, Aceh Barat, \\ ${ }^{2}$ Jurusan Ilmu Kelautan, Fakultas Perikanan dan Ilmu Kelautan, Universitas Teuku Umar, Aceh Barat, \\ ${ }^{5}$ Jurusan Sumber Daya Akuatik, Fakultas Perikanan dan Ilmu Kelautan, Universitas Teuku Umar,
}

Korespondensi : ikhsanulkhairi@utu.ac.id

\begin{abstract}
ABSTRAK
Potensi tumbuhan nipah di Indonesia sangat besar. Nipah merupakan tumbuhan mangrove yang telah dimanfaatkan secara tadisional sejak dulu baik untuk kebutuhan pangan maupun non pangan. Bagian daun dan buah nipah banyak ditemukan kandungan metabolit primer dan sekunder yang bermanfaat bagi tubuh manusia. Tujuan artikel review ini adalah mengumpulkan literatur dengan fokus kandungan metabolit primer dan sekunder di daun dan buah nipah, untuk memberikan pengatahuan potensi pengembangan produk berdasarkan kandungan metabolit yang ada pada daun dan buah nipah. Daun nipah kaya akan protein dan buah nipah kaya akan karbohidrat dan protein. Beberapa mineral trace elemen juga sangat tinggi kandungannya dalam buah nipah diantaranya yaitu natrium, magnesium dan kalium. Buah dan daun nipah mengandung beberapa metabolit sekunder seperti golongan alkaloid, flavonoid, steroid, triterpenoid, fenol, tanin dan saponin. Ekstrak daun dan buah nipah memiliki aktivitas farmakologis seperti antiinflamasi, antikanker dan antihiperglikemik. Manfaat dari metabolit primer dan sekunder yang terdapat dalam daun dan buah nipah dapat dikembangkan menjadi produk pangan fungsional dan sediaan farmasetika.
\end{abstract}

Kata kunci : Kandungan gizi, Metabolit Primer dan Sekunder, Antioksidan, Antikanker, Antiinflamasi.

\begin{abstract}
Nipa palm is huge potential in Indonesia. Nipa is a mangrove palm that has been traditionally used for both food and non-food needs. The leaves and fruit of nipa contain many primary and secondary metabolites that are beneficial to the health. The purpose of this review article is to compile the recent literature with a focus on primary and secondary metabolite content in nipah leaves and fruit, to provide insight into the potential for product development based on the content of metabolites present in nipa. nipah leaves are contain high protein and nipah fruit are contain high carbohydrates and protein. Some trace element minerals are contained in nipa fruit highly, including sodium, magnesium and potassium.

Nipa fruit and leaves contain several secondary metabolites such as alkaloids, flavonoids, steroids, triterpenoids, phenols, tannins and saponins. Nipah leaf and fruit extracts have pharmacological activities such as anti-inflammatory, anticancer and antihyperglycemic. The benefits of primary and secondary metabolites contained in palm leaves and fruit could be developed into functional food and pharmaceutical products.
\end{abstract}

Keywords : Nutrient content, Primary metabolites, Secondary metabolites, Antioksidan, Anticancer, Antiinflamation 


\section{PENDAHULUAN}

Tanaman nipah (Nypa fruticans) merupakan salah satu jenis tumbuhan palem dari total 35 genus palem yang ada di Indonesia. Tumbuhan ini tumbuh banyak di perairan yang terpengaruh dengan pasang surut (pasut) air laut (Muthmainnah dan Sribianti 2016; Subiandono et al., 2016; Rahardian et al., 2019). Tumbuhan ini dikelompokkan dalam tumbuhan hutan mangrove. Saat ini, hutan mangrove Indonesia sangat luas, yaitu mencapai 3.3 juta Ha berdasarkan citra satelit landsat, diantaranya adalah hutan mangrove. Hutan nipah di Indonesia, tersebar di pulau Sumatera, Sulawesi, Kalimantan dan Papua (Imra et al., 2016; Rahardian et al., 2019).

Masyarakat indonesia telah memanfaatkan nipah dari dahulu. Namun, hanya secara tradisional, seperti memanfaatkan daunnya untuk atap rumah dan sapu lidi serta pelepah daunnya sebagai kayu bakar (Muthmainnah dan Sribianti, 2016). Masyarakat Indonesia secara tradisional juga telah memanfaatkan nipah sebagai bahan pangan. Pemanfaatan yang dilakukan dari nipah diantaranya gula, garam serta jajanan dan tepung buah nipah (Subiandono et al 2016; Imra et al 2016).

Tumbuhan nipah dapat dimanfaatkan lebih dari masyarakat manfaatkan secara tradisional. Hasil penelitian baik dari dalam maupun luar negeri mengindikasikan tanaman nipah sarat akan manfaat bagi tubuh. Manfaat tumbuhan nipah hasi penelitian yaitu sebagai anti oksidan (Imra et al., 2016; Sabri et al., 2018; Shin et al., 2018), anti bakteri (Imra et al., 2016; Nopiyanti dan Agustriani, 2016), antiinflamasi (Bae dan Park, 2016), sebagai penstimulus sekresi insulin (Yusoff et al., 2017) dan sebagai sitoprotektif (Sari et al., 2018). Meskipun sangat banyak manfaat nipah berdasarkan hasil riset, pemanfaatan nipah di Indonesia masih sangat minim. Hal ini dikarenakan kurangnya informasi dan pengetahuan masyarakat terkait manfaat dari

tumbuhan nipah. Mengingat keterbatasan ini, maka sangat dibutuhkan informasi lebih lanjut mengenai kandungan gizi (metabolit primer) dan metabolit sekunder serta potensi pemanfaatannya sebagai pangan fungsional dan farmasetika.

\section{KANDUNGAN GIZI DAN METABOLIT SEKUNDER NIPAH}

Tanaman nipah yang dimanfaatkan sebagai pangan yaitu bagian buah dan daunnya. Kandungan karbohidrat pada buah nipah sangat tinggi dan kandungan tertinggi kedua yaitu protein. Berbeda dengan buahnya, bagian daun mengandung protein lebih tinggi. Namun, 
kandungan protein daun tua lebih tinggi dibandingkan daun muda. Komposisi proksimat nipah dapat dilihat pada Tabel 1.

Tumbuhan nipah mengandung berbagai jenis mineral di dalamnya (Khoo dan Azlan, 2020). Komposisi mineral dalam buah dan daun nipah dalam dilihat pada Tabel 2. Mineral yang terkandung di dalam buah nipah lebih sedikit jenisnya dibandingkan yang terkandung di dalam daun. Jenis mineral yang terkandung dalam buah nipah terdiri dari besi, magnesium, kalium dan natrium sedangkan jenis mineral yang terkandung dalam daun nipah terdiri dari magnesium, natrium, fosfor, selenium, clorida, kalium dan kalsium. Selain itu, beberapa hasil penelitian menunjukkan buah nipah terkandung beberapa jenis mineral lainnya, seperti potasium mencapai 128.52 mg.100 gram-1 (Osabor et al., 2008) dan magnesium mencapai 97 mg.100 gram-1 (Hoe dan Siong 1999).

Tabel 1. Komposisi proksimat nipah (Mukti et al., 2020 dan Subiandono et al., 2011)

\begin{tabular}{lccc}
\hline \multirow{2}{*}{ Jenis Uji } & \multicolumn{3}{c}{ Bagian Tumbuhan Nipah (dalam \%) } \\
\cline { 2 - 4 } & Buah & Daun Muda & Daun Tua \\
\hline Kadar air & 38.96 & - & - \\
Kadar abu & 0.98 & - & - \\
Kadar lemak & 0.7 & 1.27 & 2.33 \\
Kadar protein & 2.95 & 10.64 & 14.23 \\
Kadar karbohidrat & 56.41 & - & - \\
\hline
\end{tabular}

Keterangan:

$(-)$ : Tidak ditemukan referensi

Tabel 2. Komposisi mineral nipah (Hermat et al, 2011 dan Tamunaidu dan Saka 2011)

\begin{tabular}{lcc}
\hline \multirow{2}{*}{ Mineral } & \multicolumn{2}{c}{ Jumlah } \\
\cline { 2 - 3 } & Bagian Buah $(\mathrm{ppm})$ & Bagian Daun $(\mathrm{wt} \%)$ \\
\hline Besi & 1.07 & - \\
Magnesium & 7.97 & 0.3 \\
Kalium & 3.79 & - \\
Natrium & 9.35 & 0.4 \\
Fosfor & - & 0.3 \\
Selenium & - & 0.3 \\
Clorida & - & 0.7 \\
Kalium & - & 1.6 \\
Kalsium & - & 0.2 \\
\hline Keterangan & &
\end{tabular}

(-) : Tidak ditemukan referensi 
Tanaman nipah juga memiliki kandungan metabolit sekunder. Buah nipah mengandung beberapa senyawa metabolit sekunder, diantaranya golongan flavonoid, fenol, tanin dan saponin. Apabila dibandingkan dengan bagian buah, bagian daun cenderung lebih kaya akan metabolit sekunder. Kandungan metabolit sekunder pada daun nipah diantaranya golongan alkaloid, flavonoid, steroid, triterpenoid, tanin dan saponin. Informasi tabulasi kandungan metabolit sekunder pada tanaman nipah dapat dilihat pada Tabel 3 .

Tabel 3. Kandungan fitokimia pada tumbuhan nipah (Lestari et al., 2016; Gazali et al., 2019; Astuti et al., 2019)

\begin{tabular}{lcc}
\hline \multirow{2}{*}{ Jenis Uji } & \multicolumn{2}{c}{ Bagian Tumbuhan Nipah } \\
\cline { 2 - 3 } & Buah & Daun \\
\hline Alkaloid & - & + \\
Flavonoid & + & + \\
Steroid & - & + \\
Triterpenoid & - & + \\
Fenol & + & + \\
Tanin & + & + \\
Saponin & + & + \\
\hline
\end{tabular}

Keterangan:

(-) : Tidak ditemukan referensi

\section{PENGEMBANGAN PRODUK NIPAH SEBAGAI PANGAN FUNGSIONAL}

Pangan fungsional merupakan pangan olahan yang terkandung komponen fungsional di dalamnya dan mempunyai fungsi fisiologis tertentu berdasarkan kajian ilmiah serta tidak membahayakan kesehatan manusia. Pangan fungsional diatur dalam regulasi BPOM No.HK.00.05.52.0685 tahun 2005 tentang ketentuan pokok pengawasan pangan fungsional. Regulasi ini mengatur komponen pangan fungsional dikelompokkan dalam beberapa golongan. Golongan komponen pangan fungsional yang dimaksud dapat dilihat pada Tabel 4.

Secara umum, komponen pangan di dalam buah dan daun nipah tergolong dalam golongan komponen pangan fungsional berdasarkan Tabel 3. Golongan pertama yang ditemukan dalam tumbuhan nipah yaitu vitamin. Jenis vitamin yang terkandung dalam nipah menurut hasil penelitian Osabor et al (2008);Lim (2012);Akpabio et al (2007) adalah vitamin A dan C. Golongan kedua yaitu mineral. Hasil penelitian Hermat et al, (2011); Tamunaidu dan Saka (2011);Osabor et al., (2008);Hoe dan Siong (1999) menyebutkan pada buah dan daun nipah terdapat lebih dari sebelas jenis mineral yang sangat dibutuhkan oleh tubuh. Jenis mineral 
dengan jumlah terbanyak yang terkandung dalam buah nipah yaitu potasium, natrium dan magnesium.

Tabel 4. Komponen pangan fungsional

\begin{tabular}{cc}
\hline No & Komponen bioaktif \\
\hline 1 & Vitamin \\
2 & Mineral \\
3 & Gula alkohol \\
4 & Asam lemak tidak jenuh \\
5 & Peptida dan protein tertentu \\
6 & Asam amino \\
7 & Serat pangan \\
8 & Prebiotik \\
9 & Probiotik \\
10 & Kolin, Lestitin dan Inositol \\
11 & Karnitin dan Skualen \\
12 & Isoflavon \\
13 & Fitosterol dan Fitostanol \\
14 & Polifenol \\
\hline
\end{tabular}

Potasium sangat dibutuhkan oleh manusia. Menurut Weaver et al, (2018) serta Sun dan Weaver (2020) defiesiensi potasium dapat menyebabkan hipokalemia. Selain itu, potasium dapat mengurangi risiko penyakit kardiovaskular, stroke serta melindungi dari keropos tulang. Rekomendasi kebutuhan senyawa potasium untuk manusia umur 18 hingga 65 tahun menurut European Food Safety Authority (EFSA) tahun 2016 dan World Health Organization (WHO) tahun 2012 yaitu 3500 mg per hari. Mineral terbanyak kedua yaitu natrium. Strazzulo dan Leclercq (2014) menyebutkan natrium merupakan mineral esensial (penting) bagi tubuh manusia. Natrium berperan dalam mengatur homeostasis sel, keseimbangan cairan tubuh dan elektrolit serta tekanan darah. Rekomendasi konsumsi natrium untuk manusia menurut FDA (2020) yaitu kurang dari $2.300 \mathrm{mg}$ setiap harinya. Mineral ketiga yaitu magnesium. Magnesium juga memiliki peran penting bagi tubuh manusia. Jahnen-Dechent dan Ketteler (2012) menyebutkan magnesium dapat menstimulus pengambilan kembali kalsium oleh ATPase dari retikulum sarkoplasma dan mampu memodulasi transduksi sinyal insulin serta proliferasi sel, hal ini penting untuk adhesi sel dan transportasi transmembran. Jumlah kandungan mineral magnesium, natrium dan kalium dalam buah nipah mencapai masing-masing 7.97 ppm, 9.35 ppm dan 3.79 ppm (setara dengan $7.97 \mathrm{mg} / \mathrm{Kg}, 9.35 \mathrm{mg} / \mathrm{Kg}$ dan $3.79 \mathrm{mg} / \mathrm{Kg}$ ) (Hermat et al, 
2011 dan Tamunaidu dan Saka 2011). Selain ketiga jenis mineral ini, dalam buah dan nipah juga terkandung banyak jenis mineral lain.

Golongan komponen pangan fungsional ketiga yang terkandung dalam nipah yaitu serat pangan. Kandungan serat pangan ditemukan dalam buah nipah. Hasil Penelitian Dalming et al (2018) menyebutkan serat kasar di dalam buah nipah mencapai 46,18\%. Hasil penelitian ini juga disebutkan serat buah nipah mampu mengikat kolesterol secara in vitro. Penelitian lainnya, yang dilakukan oleh Subiandono et al (2011) menunjukkan serat pada buah nipah yang telah dijadikan tepung mencapai $22.11 \%$ basis kering. Serat pangan tetap bermanfaat bagi tubuh, meskipun tidak memiliki nilai gizi. Manfaat serat pangan menurut Fairudz dan Nisa (2015) yaitu dapat mencegah hiperkolesterol pada manusia dalam keadaan kelebihan berat badan dan obesitas. Peran serat lainnya bagi tubuh menurut Santoso (2011) yaitu dapat dijadikan sebagai agen penanggulangan diabetes, kanker kolon dan penyakit kardiovaskuler. Namun, konsumsi serat pangan berlebih berpotensi menimbulkan efek negatif. Jumlah konsumsi serat yang dianjurkan yaitu 30 gram setiap harinya.

Berdasarkan uraian kandungan komponen persyaratan pangan fungsional yang terkandung dalam buah dan daun nipah menunjukkan nipah sangat besar potensinya untuk dijadikan produk pangan fungsional. Pangan fungsional yang dikembangkan dari nipah sangat beraneka ragam. Buah nipah dapat dijadikan sebagai minuman sari buah dan daun nipah dapat dijadikan minuman teh dan minuman siap saji lainnya. Selain minuman, buah nipah dapat dijadikan tepung dan dikembangkan berbagai macam jenis makanan turunannya, seperti biskuit, crackers atau produk ekstruksi.

\section{PENGEMBANGAN PRODUK NIPAH SEBAGAI FARMASETIKA}

Farmasetika dapat diartikan sebagai proses mengubah entitas kimia baru (new chemical entity) atau baru menjadi obat yang dapat digunakans secara aman dan efektif oleh pasien. Farmasetika juga disebut sebagai keilmuan yang mendesain sediaan obat. Bahan kimia yang memiliki sifat farmakologis sangat banyak ditemukan di bumi. Namun, tidak semuanya dapat bekerja secara maksimal, sehingga dibutuhkan beberapa kajian seperti dosis, formulasi dan mekanisme pengirimannya di dalam tubuh.

Eksplorasi menemukan senyawa kimia organik terbaru sebagai bahan baku obat telah dilakukan oleh banyak peneliti dari berbagai negara. Saat ini, sebagian besar eksplorasi 
dilakukan pada komoditas hasil perikanan. Salah satu komoditas yang dimaksud adalah tumbuhan nipah. Penelitian-penelitian awal telah sangat banyak dilakukan. Hasil penelitian Bae dan Park (2016) menyebutkan ekstrak buah nipah mampu menginhibisi produksi nitrit dan sitokin pro-inflamasi pada dosis $200 \mu \mathrm{g} / \mathrm{ml}$. Penelitian lainnya, yang dilakukan oleh Kang dan Hyun (2020) menunjukkan ekstrak daun nipah dengan konsentrasi 500mg/kg mampu menurunkan ekspresi TRPV1, COX2, ekspresi inflamasi dan proinflamasi pada hewan tikus percobaan. Berdasarkan uraian ini menunjukkan ektrak buah dan daun nipah sangat potensial dikembangkan menjadi obat atau agen inhibitor inflamasi.

Bagian daun nipah memiliki manfaat lainnya, yaitu sebagai antikanker. Hasil penelitian Sari et al, (2018) dan Istiqomah et al, (2020) menyebutkan daun nipah mengandung polyisoprenoids. Senyawa polyisoprenoids dari daun nipah menunjukkan aktivitas antikanker secara in vitro dan mampu menurunkan proliferasi sel serta mampu menginduksi apoptosis pada sel kanker colon (usus besar). Hal ini menunjukkan ekstrak daun nipah mampu menghambat pertumbuhan dan perkembangan sel kanker colon. Ekstrak daun nipah juga dapat dijadikan sebagai antihiperglikemik. Reza et al (2011) dalam penelitiannya menyebutkan ekstrak kasar daun nipah menggunakan metanol mampu menginhibisi hiperglikemik dengan dosisi $500 \mathrm{mg} / \mathrm{kg}$ berat badan. Ekstrak daun nipah diduga mampu merangsang fungsi residu sel $\beta$ pankreas, menghasilkan efek antihiperglikemik melalui mekanisme ekstra pankreas dan meningkatkan pemanfaatan glukosa perifer.

\section{KESIMPULAN}

Pemanfaatan nipah di Indonesia hanya dilakukan secara tradisional. Namun, saat ini penelitian kandungan gizi (metabolit primer) dan metabolit sekunder telah banyak dilakukan. Tumbuhan nipah, khususnya bagian daun dan buah berpotensi dikembangkan sebagai pangan fungsional maupun sediaan farmasetika. Berbagai hasil penelitian awal nipah sangat penting untuk dilakukan penelitian lanjutan formulasi pangan fungsional dan sediaan nutrasetika agar komoditas nipah dapat termanfaatkan dengan maksimal.

\section{DAFTAR PUSTAKA}

Akpabio, U.D., Essien, U.C. and Eka, O.U. 2007. Chemical composition of the kernel of Nypa fruticans (nypa palm) and its application in confectionery preparation. Global 
Journal of Pure and Applied Sciences 13(4): 513-516.

Astuti, M.D., Nisa, K., and Mustikasari, K. 2019. Identification of chemical compounds from nipah ( Nypa fruticans Wurmb.) endosperm. BIO Web of Conferences 20:03002 di Banjarbaru 1-2 November 2019.

Bae, G., and Park, S. (2016). The anti-inflammatory effect of Nypa fruticans Wurmb, fruit on lipopolysaccharidae-induced inflammatory response on RAW 264,7 cells. Kor.J.Herbol 31(5), 79-84.

Dalming, T., Aliyah., Mufidah., Margareth, V., and Asmawati, A. 2018. Kandungan serat buah nipah (Nypa fruticans wurmb) dan potensinya dalam mengikat kolesterol secara in vitro. Media Farmasi XIV(1), 140-145.

EFSA. 2016. Diatary reference values for potassium. https://efsa.onlinelibrary.wiley.com /doi/epdf/10.2903/j.efsa.2016.4592. Diakses 16 Desember 2020.

Fairudz, A., and Nisa, K. 2015. Pengaruh serat pangan terhadap kadar kolesterol penderita overweight. Majority 4(8), 121-126.

FDA. 2020. Sodium in your diet. https://www.fda.gov/media/84261/download. Diakses 20 Desember 2020.

Gazali, M., Nufus, H., Nurjannah., and Zuriat. Eksplorasi senyawa bioaktif ekstrak daun nipah (Nypa fruticans Wurmb) asal pesisir Aceh Barat sebagai antioksidan. JPHPI 22(1): 155-163.

Herman, Rusli, R., Ilimu, E., Hamid, R., and Haeruddin. 2011. Analisis kadar mineral dalam abu buah nipa (Nypa fruticans) kaliwanggu teluk kendari Sulawesi Tenggara. J. Trop. Pharm. Chem 1(2): 100-110.

Hoe V.B., and Siong K.H. 1999. The nutritional value ofindigenous fruits and vegetables in Sarawak. Asia Pac. J. Clin. Nutr. 8 (1999) 24-31.

Imra, Tarman, K., and Desniar. (2016). Aktivitas antioksidan dan antibakteri ekstrak nipah (Nypa fruticans) terhadap Vibrio sp . isolat kepiting bakau (Scylla sp.). Jurnal Pengolahan Hasil Perikanan Indonesia, 19(3), 241-250.

Istiqomah, M. A., Hasibuan, P. A. Z., Sumaiyah, S., Yusraini, E., Oku, H., and Basyuni, M. 2020. Anticancer effects of polyisoprenoid from Nypa fruticans leaves by controlling expression of p53, EGFR, PI3K, AKT1, and mTOR genes in colon cancer (WiDr) cells. Natural Product Communications, 15(4), 1-8.

Jahnen-Dechent, W., and Ketteler, M. 2012. Magnesium basics. Clin Kidney J 5(Suppl 1), i3-i14.

Khoo, H. E., and Azlan, A. 2020. Comparison of nutrient composition of ripe and unripe fruits of Nypa fruticans. Fruits 68(6): 491-498.

Lestari, Y., Ardiningsih, P., and Nurlina. 2016. Aktivitas antibakteri gram positif dan negatif dari ekstrak dan fraksi daun nipah (Nypa fruticans Wurmb.) asal pesisir sungai kakap Kalimantan Barat. JKK 5(4): 1-8.

Lim, T.K. 2012. Nypa fruticans. In: Edible Medicinal and Non-Medicinal Plants. 
Springer: Dordrecht.

Mukti, N.C., Amin, M., and Sari, M. I. 2020. Kandungan Nutrisi dan Aktivitas Antioksidan Daun Nipah (Nypa Fruticans Wurmb) Sebagai Bahan Pakan Ikan. Jurnal Ilmiah Jurusan Budidaya Perairan 5(3): 106-114.

Muthmainnah., and Sribianti I. (2016). Nilai manfaat ekonomi tanaman nipah (Nypa fruticans) Desa Lakkang Kecamatan Tallo Kota Makassar. Jurnal Hutan Tropis, 4(2), 140-144.

Nopiyanti, H. T., Agustriani, F., Isnaini., and Melki . (2016). Skrining Nypa fruticans sebagai antibakteri Bacillus subtilis, Escherichia coli dan Staphylococcus aureus. Maspari journals 8(2), 83-90.

Osabor V.N., Egbung G.E., and Okafor P.C. 2008. Chemical profile of Nypa fruticans from cross Cross River Estuary, south eastern Nigeria. Pak. J. Nutr. 7 (1): 146-150.

Osabor, V.N., Egbung, G.E., and Okafor, P.C. 2008. Chemical profile of Nypa fruticans from cross river estuary, South Eastern Nigeria. Pakistan Journal of Nutrition 7(1): $146-150$.

Rahardian, A., Prasetyo, L. B., Setiawan, Y., and Wikantika, K. (2019). Tinjauan historis data dan informasi luas mangrove Indonesia. Media Konservasi, 24(2), 163-178.

Reza, H., Haq, W. M., Das, A. K., Rahman, S., Jahan, R., and Rahmatullah, M. 2011.

Anti-hyperglycemic and antinociceptive activity of methanol leaf and stem extract of

Nypa fruticans wurmb. Pak. J. Pharm. Sci 24(4), 485-488.

Sabri, W. M. A. W., Asaruddin, M. R. A. R., Sukairi, A. H., and Yusop, S. A. T. W. (2018). Antioxidant and Cytotoxicity Studies of Nypa fruticans (Nypa Palm Sugar) Extract. Indonesian Journal of Pharmaceutical Science and Technology, 1(1), 6569.

Santoso, A., 2011. Serat pangan (dietary fiber) dan manfaatnya bagi kesehatan. Magistra $75,35-40$.

Sari, D. P., Basyuni, M., Hasibuan, P. A. Z., Sumardi, S., Nuryawan, A., and Wati, R. (2018). Cytotoxic and antiproliferative activity of polyisoprenoids in seventeen mangroves species against WiDr colon cancer cells. Asian Pacific Journal of Cancer Prevention, 19(12), 3393-3400.

Sari, D. P., Basyuni, M., Hasibuan, P. A. Z., Sumardi, S., Nuryawan, A., and Wati, R. 2018. Cytotoxic and antiproliferative activity of polyisoprenoids in seventeen mangroves pecies against WiDr colon cancer cells. Asian Pacific Journal of Cancer Prevention 19, 3393-3400.

Shin, H. S., Lee, Y. J., Kim, J. W., Song, B. R., Lee, S. L., and Park, S. N. (2018). Evaluation of antioxidant, cytoprotective and antimicrobial activities of the extract and fractions obtained from young shoots of nypa fruticans wurmb. Korean Journal of Pharmacognosy, 49(2), 155-164.

Strazzullo, P., and Leclercq, C. 2014. Sodium. Adv Nutr 5(2), 188-190. 
Subiandono, E., Heriyanto, N. M., and Karlina, E. (2016). Potensi nipah Nypa fruticans (Thunb.) Wurmb.) sebagai sumber pangan dari hutan mangrove. Buletin Plasma Nutfah, 17(1), 54-60.

Subiandono, E., Heriyanto, N.M., dan Karlina, E. 2011. Potensi nipah (Nypa fruticans (Thunb.) Wurmb.) sebagai sumber pangan dari hutan mangrove. Buletin Plasma Nutfah 17(1): 54-60.

Sun, H., and Weaver, C. M. 2020. Rise in potassium deficiency in the us population linked to agriculture practices and dietary potassium deficits. J. Agric. Food Chem. 68(40): 11121-11127.

Tamunaidu, P., and Saka, S. 2011. Chemical characterization of various parts of nipa palm (Nypa fruticans). Industrial Crops and Products 34(2011): 1423-1428.

Weaver, C.M., Stone, M.S., Lobene, A.J., Cladis, D.P., and Hodges, J.K. 2018. What is the evidence base for a potassium requirement?. Nutrition Today 53(5): 184-195.

WHO. 2012. Guideline: Potassium Intake for Adults and Children. Geneva : WHO

Yusoff, N. A., Lim, V., Al-Hindi, B., Razak, K. N. A., Widyawati, T., Anggraini, D. R., Ahmad, M., and Asmawi, M. Z. (2017). Nypa fruticans wurmb. vinegar's aqueous extract stimulates insulin secretion and exerts hepatoprotective effect on STZinduced diabetic rats. Nutrients, 9(9): 1-12. 